\title{
Three-Dimensional Digitalized and Printed Tongue Models of the Cow, Dog, Pig, and Horse for Undergraduate Veterinary Educationh
}

\author{
Modelos Tridimensionales Digitalizados e Impresos de Lengua de Vaca, \\ Perro, Cerdo y Caballo para la Educación Veterinaria de Pregrado
}

\begin{abstract}
Bettina Assis Di Donato; Amilton Cesar dos Santos; Erick Eduardo da Silveira; Helton Carlos Sabino Pereira; Antônio Francisco da Silva Lisboa Neto; Mayla Magalhães de Oliveira Alcobaça \&Antônio Chaves de Assis Neto
\end{abstract}

DI DONATO, B. A.; DOS SANTOS, A. C.; DA SILVEIRA, E. E.; PEREIRA, H. C. S.; LISBOA NETO, A. F. S. ; ALCOBAÇA, M. M. O. \& ASSIS NETO, A. C. Three-dimensional digitalized and printed tongue models of the cow, dog, pig, and horse for undergraduate veterinary education. Int. J. Morphol., 39(2):436-440, 2021.

SUMMARY: This study aimed to construct three-dimensional (3D) anatomical models of the tongue of domestic mammals of veterinary interest. The tongues were obtained from the didactic collection of the Laboratory of Veterinary Macroscopic Anatomy in the Surgery Department of the School of Veterinary Medicine and Animal Science, University of Sao Paulo. Tongues from a cow, dog, horse, and pig were selected for scanning and creation of the 3D-printed models. The printer used a filamentous thermoplastic material, acrylonitrile-butadiene-styrene (ABS), which was deposited together with a support resin. In addition to the printing of models, an interactive 3D PDF was generated, creating a didactic collection for students. The anatomical characteristics and peculiarity of the tongues were easily identified in the scanned and printed images. The 3D scanning and printing offered an innovative method of visualizing different anatomical structures and, together with the existing methods, can optimize anatomy teaching in an educational context.

KEY WORDS: Additive manufacturing; Anatomical models; 3D models; 3D printing; Comparative anatomy.

\section{INTRODUCTION}

Three-dimensional (3D) printers were developed in the 1980s. Since then, new technologies have enabled the production of better and more accurate devices, which have been used in different industries, such as industry, engineering and medicine. A prospective trial of stereolithographic biomodelling was performed to investigate the feasibility of using this technology to accurately manufacture solid plastic replicas of anatomical structures (D'Urso et al., 1999; Bibb \& Winder, 2010).

The creation of digitalized and printed collections in $3 \mathrm{D}$ can be an effective tool for use in didactic activities in undergraduate courses. Other advantages include using these materials to complement traditional methods of anatomy teaching, and obviatingthe ethical issues involved in accessing biological tissues or cadavers (Thomas et al., 2016; Chen et al., 2017).
Anatomical specimens or models have been used since the very beginning of veterinary science and their usage has proven to be a versatile method to facilitate teaching, even with large groups of students. Therefore, from a practical perspective, $3 \mathrm{D}$ printing can be a valuable teaching tool. Universities use 3D printing as a tool to assist in teaching and have published educational reports about the method. In this environment, the technology provides both project-based learning (Reis et al., 2017) and development of models for visual learning assistance or accessibility (Ford \& Minshall, 2019; Hackmann et al., 2019; Reis et al., 2019). Preece et al. (2013) demonstrated the importance of using $3 \mathrm{D}$ models in teaching undergraduate students in veterinary medicine. Students who used physical models for identifying the anatomical structures of the horse hoof recalled information better than those who used books and/or virtual models. 
Di DONATO, B. A.; DOS SANTOS, A. C.; DA SILVEIRA, E. E.; PEREIRA, H. C. S.; LISBOA NETO, A. F. S. ; ALCOBAÇA, M. M. O. \& ASSIS NETO, A. C. Three-dimensional digitalized and printed tongue models of the cow, dog, pig, and horse for undergraduate veterinary education. Int. J. Morphol., 39(2):436-440, 2021.

The use of 3D models has been promoted for the training and qualification of medical professionals.Its benefits include assisting in diagnosis, surgical planning, and reductions in the length of operative procedures, the period of anesthesia, the risks of infections, the number of surgeries necessary to obtain a final result and the overall costs of a treatment.Studies have also presented the possibility of 3D printing of biomaterials, cells, and components of tissue supports used in regenerative medicine (Paiva et al., 2007; Robiony et al., 2007; Meléndez-Álvarez, 2009; Ferraz et al., 2013; Thomas et al.). The aim of the present study was to build 3D virtual and physical models of the tongues of different domestic mammalian species (cow, dog, horse, and pig) in order to construct a didactic collection for the study of veterinary anatomy.

\section{MATERIAL AND METHOD}

Samples. The biological material came from the didactic collection of the Laboratory of Veterinary Macroscopic Anatomy at the Surgery Department of the School of Veterinary Medicine and Animal Science, University of Sao Paulo, Brazil. Tongues from a cow, dog, horse, and pig were selected for capturing 3D images and creation of 3D-printed models. The study was approved by the Ethics Committee on Animal Use of the Faculty of Veterinary Medicine and Animal Science, University of São Paulo, São Paulo, Brazil (reference number 6323261119).

3D scanning and editing procedures. The tongues were digitalized using the "3D Go! SCAN" model (Creaform Inc. Lévis, Quebec, Canada). This portable 3D scanner acquires data through triangulations, using two acquisition cameras and a laser cannon. The scanned images were viewed on a computer (Laptop; 16Gb, Windows ${ }^{\circledR}$ Pro, 64 bit) through the VXElements program(Lévis, Quebec, Canada). The generated images were exported to the Standard Triangulation Language (STL) format and edited using the software Geomagic Inc (Cary, NC, USA). This step was essential so that the scanned piece was as close as possible to the original piece, maintaining its anatomical structures. In the program it was possible to generate a $3 \mathrm{DPDF}$, in which structures could be identified, and the file could be exported to a format that can be printed on a $3 \mathrm{D}$ printer.

3D printing and washing of models. After the scanning and editing processes, the generated images were printed using the 3D printer-mojo ${ }^{\circ}$ (Rehovot, Israel). The file was saved in the STL (binary) format and, with the Print Wizard software, the file was prepared for printing. The printer used the Fused Deposition Modeling TM (FDM) technology in the form of a thermoplastic filament-shaped material (acrylonitrile-butadiene-styrene, ABS) that was deposited together with support resin on a removable semi-adherent base $(12.7 \mathrm{~cm} ¥ 12.7 \mathrm{~cm})$. Printed parts were cleaned in a WaveWash 55 - Stratasys ${ }^{\circledR}$ (Rehovot, Israel) washer to remove the support resin, thereby leaving only the part that was being manufactured. In the cleaning process, which lasted approximately $8 \mathrm{~h}$, the washer used a specific cleaning agent (Econoworks Tables Cleaning Agent $\AA$ ) that removed only the support resin. The printed models were infilled with ABS.

\section{RESULTS}

The 3D models of the tongue of dog, cow, horse and pig were printed from an interface that was able to convert the $3 \mathrm{D}$ file into print layers. For each of tongue, the printing process lasted about $4 \mathrm{~h} 40 \mathrm{~min}$. The pieces were subjected to the washing process to remove the support resin. The anatomical characteristics of the tongues and the $3 \mathrm{D}$ printed model were analyzed visually and compared with details in current veterinary anatomy textbooks of animal domestics mammals (Nickel et al., 1981; Dyce et al., 2010; König \& Liebich, 2011; International Committee on Veterinary Gross Anatomical Nomenclature, 2012) (Fig. 1A-D).

The real, scanned, and printed models of the bovine tongue are depicted in Figure 1A. The tongue is regionally divided into the root, body, and apex. The apex, which is free and pointed, has a rounded margin. A peculiarity of the bovine tongue is the presence of the lingual torus, characterized as a dorsal prominence in the body of the tongue. It also has a deep lingual fossa on its dorso-rostral portion and the absence of a longitudinal groove on its dorsal surface. From the images generated by PDF and 3D printing, it was possible to observe clearly the correspondence of the macroscopic characteristics of the models with the characteristics of a real bovine tongue. On the surface of the $3 \mathrm{D}$ models the main anatomical characteristics of the species were conserved.

The tongue of the horse is characterized by a discrete lingual torus and a discrete groove in the region of the dorsal surface. The edge of the apex is slightly rounded. These characteristics were reproduced reliably in the scanned and printed models (Fig. 1B). The tongue of thepig is characterized by being long and narrow, and by a very fine and pointed apex. The anatomical characteristics of the tongue were easily identified in the scanned and printed images (Fig. 1C). The canine tongue has an enlarged shape. It is thin in the rostral portion and thick in the caudal portion. 
A striking feature of the species is the median groove, which extends dorsally from the root to the apex. These
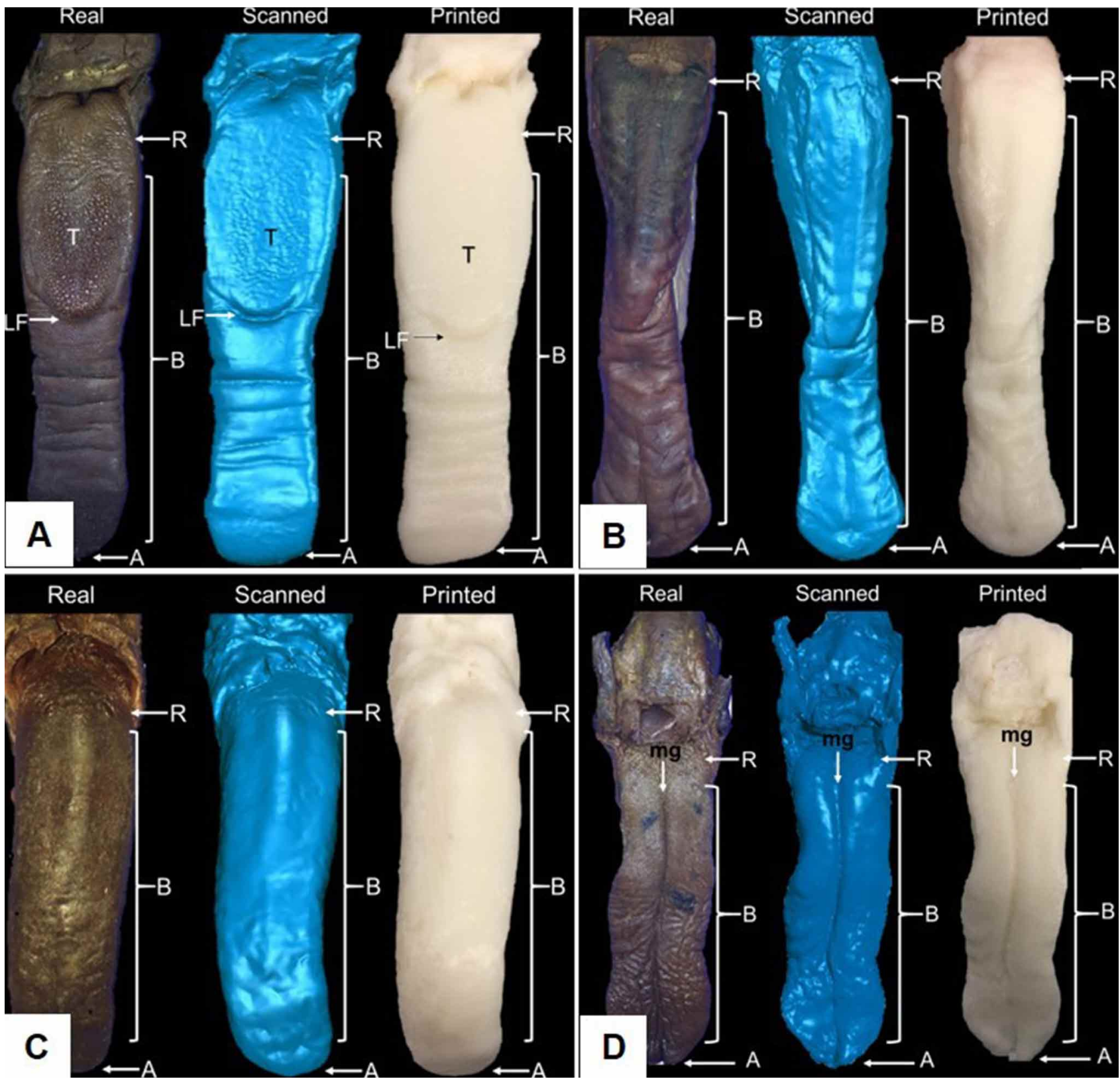

Fig. 1. (A) Tongue of the cow. $\mathrm{R}=$ root; $\mathrm{B}=$ body; $\mathrm{A}=$ apex; $\mathrm{T}=$ lingual torus; $\mathrm{LF}=$ lingual fossa.(B) Tongue of the horse. $\mathrm{R}=$ root; $\mathrm{B}=$

body; $\mathrm{A}=$ apex. $(\mathrm{C})$ Tongue of the pig. $\mathrm{R}=\operatorname{root} ; \mathrm{B}=$ body; $\mathrm{A}=$ apex. (D) Tongue of the dog. $\mathrm{R}=\operatorname{root} ; \mathrm{B}=\mathrm{body} ; \mathrm{A}=\mathrm{apex}$; mg= median groove.

\section{DISCUSSION}

From the models scanned in 3D, a dynamic digital collection was built for the study of the comparative anatomy of the tongue of domestic animals, which can be used to complement practical classes of veterinary anatomy. In macroscopic features, with clarity of detail, could be viewed in the real, scanned and printed models (Fig. 1D).

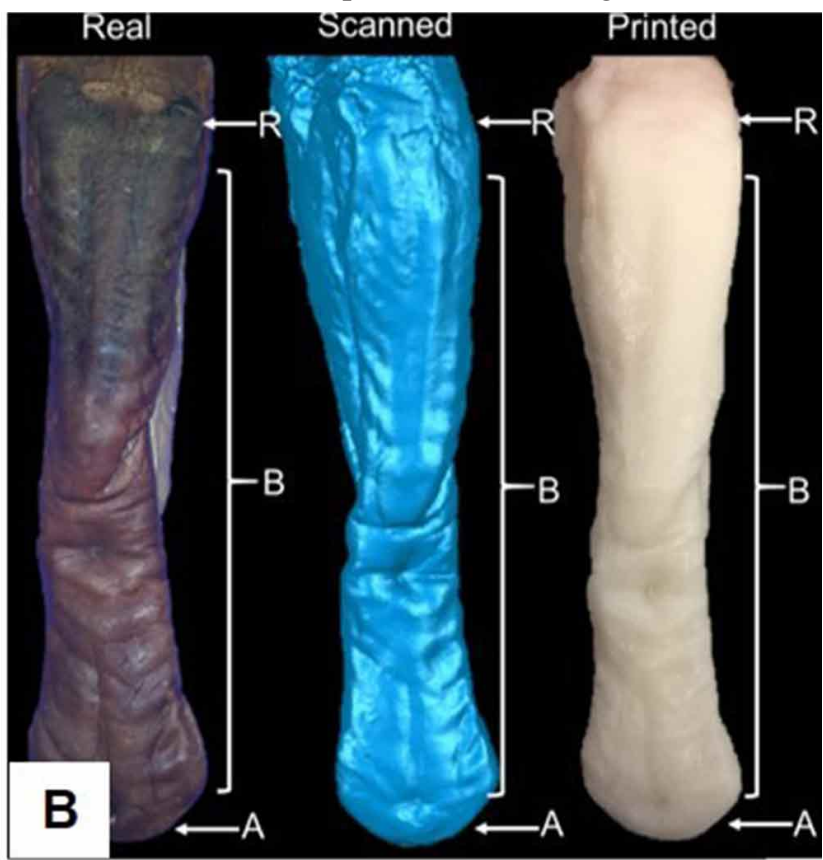

addition, the creation of a collection of anatomical models printed in 3D can reduce the need for the use of cadavers or parts of cadavers in class. The digital collection, as well as the printed models, are an important tool for teaching anatomy. 
DI DONATO, B. A.; DOS SANTOS, A. C.; DA SILVEIRA, E. E.; PEREIRA, H. C. S.; LISBOA NETO, A. F. S. ; ALCOBAÇA, M. M. O. \& ASSIS NETO, A. C. Three-dimensional digitalized and printed tongue models of the cow, dog, pig, and horse for undergraduate veterinary education. Int. J. Morphol., 39(2):436-440, 2021.

Anatomy is a discipline that is extremely dependent on the pre-existing visualization skills and spatial perception of the students, including the ability to interpret drawings, pictures, models, and real anatomical structures. The success in anatomy learning and comprehension is directly linked to these skills (Barger, 2016; Husmann et al., 2016). Visual literacy has been a growing concern in the last few decades in the teaching several science courses, and efforts are presented in the literature to create guidelines towards the development of assessment, practices and didactic resources for visual learning skills (Schönborn \& Anderson, 2006; Arneson \& Offerdahl, 2018). Thus, anatomy relies strongly on visual information and involves an intense cognitive load to learn.

The low cost and the durability of 3D printed models are usually cited among its advantages. However, there is a less obvious benefit (Rengier et al., 2010): the wide possibilities of customizations, which could be directed to facilitate the comprehension of the content of a discipline. Three-dimensional printing has been widely utilized in human medicine, either as educational motivation or models for surgical applications (Hespel et al., 2014; Hoang et al., 2016; Martelli, et al., 2016). It has also been used in veterinary medicine for similar purposes or for anatomical reconstruction (Rafan et al., 2017). Nevertheless, there is scarce literature reporting the validity and effectiveness of $3 \mathrm{D}$ printing when used in fundamental course subjects, such as veterinary anatomy (Hart et al., 2005; Schoenfeld-Tacher et al., 2017; Winer et al., 2017; Hespel, 2018; Kim et al., 2018; Suñol et al., 2019).

In all scanned models, it was necessary to use targets so that the surfaces of the tongues were better identified and scanned. Being larger in size, the tongues of the cow and horse were more easily captured by the scanner, allowing a better clarity of the anatomical particularities. Still, in all cases, it was difficult for the light of the scanner to reach the parts that correspond to the root of the tongue and for these parts to be captured, because they have recesses. Despite using the best resolution $(0.5 \mathrm{~mm})$ of the VX Elements program, it was difficult to scan the textured surface of the lingual papillae. The topography of the lingual papillae, although evident in the root and tongue body of the physical models, was lost in the process of scanning and printing. However, this does not invalidate the quality of the material as a didactic product, and these anatomical structures can be represented by painting them on the finished model. The editing process was performed to correct glitches and fill in spaces that were not captured by the scanner. Through Geomagic Software, it was possible to correct these details. Therefore, we recommend having an in-depth knowledge of the Geomagic program, so that the edits are carried out in an appropriate way.
When it comes to constructing a didactic collection for educational purposes, the implementation of 3D models has proved to be a valuable tool. We emphasize the value of this tool for teaching in resource-poor environments. The "gold standard" for teaching anatomy is considered to be dissection of cadavers, which favors the recognition of the positional relationships of the organs and the spatial relationships between structures. However, with the difficulty of accessing cadavers (mainly due to ethical issues), many institutions have adopted alternative methods for teaching anatomy. In circumstances where cadaver dissection is limited, students rely heavily on 2D visual representations. According to Preece et al., the 2D visualization method alone is not $100 \%$ effective because it does not favor the acquisition and retention of knowledge. Tactile manipulation during cadaver dissection activates multiple senses, which promotes better understanding and the retention of information when compared to the use of digital models. The $3 \mathrm{D}$ printed anatomical models may be an alternative way to study anatomy when dissection is inaccessible (McMenamin et al., 2014). This method could also be applicable to resource-poor students, since universities can freely provide on their digital teaching platforms. The accuracy and reliability of the printed models was confirmed by comparative analyses of the anatomical characteristics of the tongues (digitalized, printed and real). Future studies involving a test of $3 \mathrm{D}$ printed tongues with students may show these are a valuable aid in anatomy lessons and can serve as reliable alternatives in the study of veterinary anatomy. The 3D models can be used to complement anatomy teaching in veterinary courses, provided they are introduced in a carefully planned manner. The choice of the model to be scanned must be done in a careful way, so that the anatomical characteristics required are evident. Editing by a professional veterinarian is a fundamental part of the process because it allows the reconciliation of the scanned and real models.

\section{CONCLUSION}

Three-dimensional scanning and printing offer an innovative method of visualizing different anatomical structures and, together with existing methods, can optimize anatomy teaching in an educational context.

\section{ACKNOWLEDGEMENTS}

We would like to thank University of Sao Paulo (PUB Program) for scholarship to undergraduate researches assistants and, Editage for English language editing. 
$\overline{\text { DI DONATO, B. A.; DOS SANTOS, A. C.; DA SILVEIRA, E. E.; }}$ PEREIRA, H. C. S.; LISBOA NETO, A. F. S. ; ALCOBAÇA, M. M. O. \& ASSIS NETO, A. C. Modelos tridimensionales digitalizados e impresos de lengua de vaca, perro, cerdo y caballo para la educación veterinaria de pregrado. Int. J. Morphol., 39(2):436-440, 2021.

RESUMEN: Este estudio tuvo como objetivo construir modelos anatómicos tridimensionales (3D) de la lengua de mamíferos domésticos de interés veterinario. Las lenguas se obtuvieron de la colección didáctica del Laboratorio de Anatomía Macroscópica Veterinaria del Departamento de Cirugía de la Facultad de Medicina Veterinaria y Zootecnia de la Universidad de São Paulo. Se seleccionaron lenguas de vaca, perro, caballo y cerdo para escanear y crear los modelos impresos en 3D. La impresora utilizó un material termoplástico filamentoso, acrilonitrilo-butadieno-estireno (ABS), que se depositó junto con una resina de soporte. Además de la impresión de modelos, se generó un PDF 3D interactivo, creando una colección didáctica para los estudiantes. Las características anatómicas y la peculiaridad de las lenguas se identificaron fácilmente en las imágenes escaneadas e impresas. El escaneo e impresión 3D ofrecieron un método innovador para visualizar diferentes estructuras anatómicas y, junto con los métodos existentes, puede optimizar la enseñanza de la anatomía en un contexto educativo.

PALABRAS CLAVE: Fabricación aditiva; Modelos anatómicos; Modelos 3D; Impresión 3D; Anatomía comparada.

\section{REFERENCES}

Arneson, J. B. \& Offerdahl, E. G. Visual literacy in Bloom: Using Bloom's taxonomy to support visual learning skills. CBE Life Sci. Educ., 17(1):ar7, 2018.

Barger, B. Teaching students to see: visual learning instruction for two different undergraduate anatomy courses. FASEB J., 30(S1):570.10-570.10, 2016.

Bibb, R. \& Winder, J. A review of the issues surrounding three-dimensional computed tomography for medical modelling using rapid prototyping techniques. Radiography, 16(1):78-83, 2010.

Chen, S.; Pan, Z.; Wu, Y.; Gu, Z.; Li, M.; Liang, Z.; Zhu, H.; Yao, Y.; Shui, W.; Shen, Z.; et al. The role of three-dimensional printed models of skull in anatomy education: a randomized controlled trail. Sci. Rep., 7(1):575-86, 2017.

D’Urso, P. S.; Thompson, R. G.; Atkinson, R. L.; Weidmann, M. J.; Redmond, M. J.; Hall, B. I.; Jeavons, S. J.; Benson, M. D. \& Earwaker, W. J. Cerebrovascular biomodelling: a technical note. Surg. Neurol., 52(5):490-500, 1999.

Dyce, K. M.; Sack, W. O. \& Wensing, C. J. G. Tratado de Anatomia Veterinária. Rio de Janeiro, Elsevier Science, 2010. pp.856.

Ferraz, E. G.; Andrade, L. C. S.; dos Santos, A. R.; Torregrossa, V. R.; RubiraBullen, I. R. F. \& Sarmento, V. A. Application of two segmentation protocols during the processing of virtual images in rapid prototyping: ex vivo study with human dry mandibles. Clin. Oral Investig., 17(9):2113-8, 2013.

Ford, S. \& Minshall, T. Invited review article: Where and how 3D printing is used in teaching and education. Addit. Manuf., 25:131-50, 2019.

Hackmann, C. H.; Dos-Reis, D. A. L. \& De-Assis-Neto, A. C. Digital revolution in veterinary anatomy: confection of anatomical models of canine stomach by scanning and three-dimensional printing (3D). Int. J. Morphol., 37(2):48690, 2019.

Hart, L. A.; Wood, M. W. \& Weng, H. Y. Mainstreaming alternatives in veterinary medical education: resource development and curricular reform. J. Vet. Med. Educ., 32(4):473-80, 2005.

Hespel, A. M. Three-dimensional printing role in neurologic disease. Vet. Clin. North Am. Small Anim. Pract., 48(1):221-9, 2018.

Hespel, A. M.; Wilhite, R. \& Hudson, J. Invited review--Applications for 3D printers in veterinary medicine. Vet. Radiol. Ultrasound, 55(4):347-58, 2014.

Hoang, D.; Perrault, D.; Stevanovic, M. \& Ghiassi, A. Surgical applications of three-dimensional printing: a review of the current literature \& how to get started. Ann. Transl. Med., 4(23):456, 2016.

Husmann, P. R.; Barger, J. B. \& Schutte, A. F. Study skills in anatomy and physiology: Is there a difference? Anat. Sci. Educ., 9(1):18-27, 2016.
International Committee on Veterinary Gross Anatomical Nomenclature. Nomina Anatomica Veterinary. Technical Report. Knowville, World Association on Veterinary Anatomist, 2012, pp.177.

Kim, S. E.; Shim, K. M.; Jang, K.; Shim, J. H. \& Kang, S. S. Three-dimensional printing-based reconstruction of a maxillary bone defect in a dog following tumor removal. In Vivo, 32(1):63-70, 2018.

König, H. \& Liebich, H. Anatomia dos Animais Domésticos. Porto Alegre, Artmed, 2011. pp.824.

Martelli, N.; Serrano, C.; van den Brink, H.; Pineu, J.; Prognon, P.; Borget, I. \& El Batt, S. Advantages and disadvantages of 3-dimensional printing in surgery: A systematic review. Surgery, 159(6):1485-500, 2016.

McMenamin, P. G.; Quayle, M. R.; McHenry, C. R. \& Adams, J. W. The production of anatomical teaching resources using three-dimensional (3D) printing technology. Anat. Sci. Educ., 7(6):479-86, 2014.

Meléndez-Álvarez, B. F. Entornos virtuais como apoio ao aprendizado da anatomia em medicina. Investig. Andina, 11(19):94-106, 2009.

Nickel, R.; Schummer, A. \& Seiferle, E. The Anatomy of Domestic Animals. Berlin, Verlag Paul Parey, 1981. pp.600.

Paiva, W. S.; Amorim, R.; Bezerra, D. A. F. \& Masini, M. Aplication of the stereolithography technique in complex spine surgery. Arq. Neuropsiquiatr. 65(2B):443-5, 2007.

Preece, D.; Williams, S. B.; Lam, R. \& Weller, R. "Let's get physical": advantages of a physical model over 3D computer models and textbooks in learning imaging anatomy. Anat. Sci. Educ., 6(4):216-24, 2013.

Rafan, H.; Guevar, J.; Poyade, M. \& Rea, P. M. Canine neuroanatomy: Development of a $3 \mathrm{D}$ reconstruction and interactive application for undergraduate veterinary education. PLoS One, 12(2):e0168911, 2017.

Reis, D. A. L.; Gouveia, B. L. R.; Alcântara, B. M. \& Assis Neto, A. C. Bone biomodels produced using 3D printing: A methodological alternative in teaching veterinary anatomy. Rev. Grad. USP, 2:47-53, 2017.

Reis, D. A. L.; Gouveia, B. L. R.; Rosa Júnior, J. C. \& de Assis Neto, A. C. Comparative assessment of anatomical details of thoracic limb bones of a horse to that of models produced via scanning and 3D printing. $3 D$ Print. Med., 5(1):13, 2019.

Rengier, F.; Mehndiratta, A.; von Tengg-Kobligk, H.; Zechmann, C. M.; Kauczor, H. U. \& Giesel, F. L. 3D printing based on imaging data: review of medical applications. Int. J. Comput. Assist. Radiol. Surg., 5(4):335-41, 2010.

Robiony, M.; Salvo, I.; Costa, F.; Zerman, N.; Bazzocchi, M.; Toso, F.; Bandera, C.; Filippi, S.; Felice, M. \& Politi, M. Virtual reality surgical planning for maxillofacial distraction osteogenesis: the role of reverse engineering rapid prototyping and cooperative work. J. Oral Maxillofac. Surg., 65(6):1198-208, 2007.

Schoenfeld-Tacher, R. M.; Horn, T. J.; Scheviak, T. A.; Royal, K. D. \& Hudson, L. C. Evaluation of 3D additively manufactured canine brain models for teaching veterinary neuroanatomy. J. Vet. Med. Educ., 44(4):612-9, 2017.

Schönborn, K. J. \& Anderson, T. R. The importance of visual literacy in the education of biochemists. Biochem. Mol. Biol. Educ., 34(2):94-102, 2006.

Suñol, A.; Aige, V.; Morales, C.; López-Beltran, M.; Feliu-Pascual, A. L. \& Puig, J. Use of three-dimensional printing models for veterinary medical education: impact on learning how to identify canine vertebral fractures. J. Vet. Med. Educ., 46(4):523-32, 2019.

Thomas, D. B.; Hiscox, J. D.; Dixon, B. J. \& Potgieter, J. 3D scanning and printing skeletal tissues for anatomy education. J. Anat., 229(3):473-81, 2016.

Winer, J. N.; Verstraete, F. J. M.; Cissell, D. D.; Lucero, S.; Athenasiou, K. A. \& Arzi, B. The application of 3-dimensional printing for preoperative planning in oral and maxillofacial surgery in dogs and cats. Vet. Surg., 46(7):942-51, 2017.

Corresponding author:

Antônio Chaves de Assis Neto

Surgery Department of the School of Veterinary

Medicine and Animal Science

University of São Paulo

Avenida Prof. Dr. Orlando Marques de Paiva, 87

São Paulo/SP - BRAZIL

E-mail: antonioassis@usp.br

Received: 28-09-2020

Accepted: 01-12-2020 